\title{
Uma análise da violência entre os jovens no Bairro Barroso em Fortaleza/CE
}

An analysis of violence among young people in neighborhood in Fortaleza/CE

Un análisis de la violencia entre los jóvenes del barrio Barroso en Fortaleza/CE

\author{
Lourenço Lionzo \\ lorenzo_lionzo@hotmail.com \\ https://orcid.org/0000-0001-5575-4545 \\ Universidade de Coimbra - Portugal
}

\begin{abstract}
RESUMO
A violência, tão discutida na sociedade contemporânea devido às mazelas sociais que provoca, ao materializar-se, traz à luz o debate acerca da sua origem. Todavia, o fenômeno não é estático ou intrínseco, pois se expressa por meio de significados oriundos do processo das relações sociais, resultantes das mudanças na divisão e, da apropriação do fruto do trabalho. $\mathrm{O}$ artigo analisa a existência da relação entre a vulnerabilidade social e a violência entre os jovens do bairro Barroso em Fortaleza/Ceará. A metodologia é descritiva com abordagem qualitativa, tendo sido entrevistadas a presidente da Associação Sol da Manhã e cinco famílias que tiveram jovens assassinados. Constatou-se que, a relação entre homicídios e a vulnerabilidade social, perpassa a carência e má qualidade da educação e da segurança pública. O problema está relacionado a sobreposição de carências materializadas nas relações de exclusão social, como por exemplo, nas más condições de: habitação, da educação, no desemprego, na inacessibilidade ao lazer e nos estigmas que esses sujeitos carregam.
\end{abstract}

Palavras-chave: Vulnerabilidade Social e Risco Social. Violência. Jovens.

\begin{abstract}
Violence, so discussed in contemporary society due to the social ills it causes, when materializing, brings to light the debate about its origin. However, the phenomenon is not static or intrinsic, as it'is expressed through meanings derived from the process of social relations, resulting from changes in the division and the appropriation of the fruit of work. The article analyzes the existence of the relationship between social vulnerability and violence among young people in the Barroso neighborhood in Fortaleza/Ceará. The methodology is descriptive with a qualitative approach, having been interviewed the president of the Sol da Manhã Association and five families that had young people murdered. It was found that the relationship between homicides and social vulnerability runs through the lack and poor quality of education and public security. The problem is related to the overlapping of materialized needs in social exclusion relationships, such as, for example, the poor conditions of: housing, education, unemployment, inaccessibility to leisure and the stigmas that these subjects carry.
\end{abstract}

Keywords: Social Vulnerability and Social Risk. Violence. Young.

\section{RESUMEN}

La violencia, tan discutida en la sociedad contemporánea por los males sociales que provoca, al materializarse, saca a la luz el debate sobre su origen. Sin embargo, el fenómeno no es estático ni intrínseco, ya que se expresa a través de significados derivados del proceso de relaciones sociales, resultado de cambios en la división y apropiación del fruto del trabajo. El artículo analiza la existencia de la relación entre vulnerabilidad social y violencia entre los jóvenes del barrio Barroso en Fortaleza / Ceará. La metodología es descriptiva con un enfoque cualitativo, habiendo sido entrevistado el presidente de la Asociación Sol da Manhã y cinco familias que tenían jóvenes asesinados. Se encontró que la relación entre homicidios y vulnerabilidad social pasa por la falta y mala calidad de la educación y seguridad pública. El problema está relacionado con la superposición de necesidades materializadas en las relaciones de exclusión social, como, por ejemplo, las malas condiciones de: vivienda, educación, desempleo, inaccesibilidad al ocio y los estigmas que estos sujetos cargan.

Palabras clave / identificadores: Vulnerabilidad social y riesgo social. Violencia. Jóvenes. 


\section{INTRODUÇÃO}

O fenômeno da violência aflorou como um problema para os indivíduos e para as mais diversas sociedades contemporâneas. Quem nunca se indagou ao menos uma vez como seria possível enfrentar a questão da violência, um tema tão debatido que vem se agravando. As respostas para essa questão, dadas pelas sociedades, têm se mostrado múltiplas, abrangendo uma gama de medidas, nos mais diversos níveis: individual, comunitário e governamental, muitas vezes banalizado, que bate em nossas portas cotidianamente de forma direta ou indireta.

No Brasil, tal fenômeno não é diferente e nem menos importante. Historicamente, o processo de migração da população rural em direção às grandes cidades, devido à mudança no modelo econômico produtivo agroexportador até a década de 1930, para um modelo industrial, como afirma Furtado (1977), acarretou em uma reestruturação da sociedade e consequentemente no crescimento do fenômeno chamado violência.

Para Waiselfisz (2000), no século passado, entre os anos 1930 até meados de 1991 a mortalidade entre os jovens no Brasil, eram em decorrência do alto percentual de epidemias e doenças infeciosas. Todavia, essa realidade foi sendo paulatinamente alterada ainda no século passado a partir dos anos de 1980, quando o homicídio e o acidente de trânsito passam a representar $52,9 \%$ do total das mortes dos jovens no País.

Diante da relevância do tema, na segunda metade da década de 1990, foram realizados uma série de quatro estudos sob o título "Juventude, Violência e Cidadania", pela Organização das Nações Unidas para a Educação, Ciência e Cultura (UNESCO), em quatro grandes capitais: Brasília, Curitiba, Rio de Janeiro e Fortaleza.

Nos anos de 2011, segundo dados do Centro Brasileiro de Estudos Latino-Americanos (CEBELA), a taxa de homicídio da população total no Brasil era de 27,1 homicídios por 100 mil habitantes, superando, inclusive os índices dos outros 11 países mais populosos do mundo (China, Índia, USA, Indonésia, Paquistão, Nigéria, Bangladesh, Rússia, Japão, México e Filipinas).

No tocante à violência, na cidade de Fortaleza, segundo estudo realizado pelo Instituto de Pesquisa e Estratégia Econômica do Ceará (IPECE, 2012), os homicídios na Capital estavam associados a localização geográfica de alguns bairros que possuíam as seguintes características: alta densidade demográfica entre jovens de 11 a 29 anos; maiores níveis de pobreza; menores taxas de alfabetização e menores rendas domiciliares per capita.

Diante dos dados apresentados, dos estudos supramencionados e sabendo-se de antemão que o bairro Barroso entre os anos de 2012 e 2013 se encontrava entre as dez áreas da cidade onde mais ocorriam homicídios, passou-se a indagar: se há e como se dá a relação entre homicídios e vulnerabilidade social ${ }^{1}$, entre os jovens, das famílias acometidas pela violência no bairro Barroso, na cidade de Fortaleza? Assim, o presente artigo analisou a possível relação entre violência e vulnerabilidade social entre os jovens, na perspectiva dos familiares, acometidos por este fato do bairro Barroso, em Fortaleza - Ceará, dentre os anos de 2012 e 2013.

O interesse pela temática deve-se ao fato de sermos da Região Sul do Brasil e termos passado a maior parte da nossa vida morando lá, e posteriormente termos residido também na Europa. Desse modo, passou-se a observar, mesmo de forma empírica, uma diferença muito grande nos índices de violência (homicídio), entre os jovens da cidade de Fortaleza em relação à ao Sul do Brasil. Ressalta-se que, esta constatação não se deu apenas por relatos, ou dados divulgados pelos meios de comunicação, mas também, pela forma com que as pessoas andavam pelas ruas em

\footnotetext{
${ }^{1}$ Vulnerabilidade social entendida como a zona intermediária instável que conjuga a precariedade do trabalho e a fragilidade dos suportes de proximidade (CASTEL, 1998).
} 
Fortaleza: "com o medo a transparecer em seus olhos, nos andares sempre vigilantes, preocupadas com a violência que pode estar à sua espreita na próxima esquina".

O presente artigo foi dividido em três sessões, quais sejam: a aproximação com as categorias de análise, no caso, os pressupostos teóricos acerca do entendimento sobre no que consiste a violência e os conceitos sobre vulnerabilidade social \& risco social; a metodologia que foi utilizada para realizar o estudo, bem como a apresentação do campo do estudo; e análise dos achados da pesquisa. Por fim, é apresentado as considerações finais.

\section{FUNDAMENTAÇÃO TEÓRICA}

Inúmeros pesquisadores de diferentes correntes teóricas dentro da literatura debatem de forma "árdua" o tema "violência", pois além de ser um problema enfrentando pelas sociedades não existe um consenso entre os mesmos quanto: às causas que produzem a violência; às possíveis soluções; e nem mesmo quanto ao fenômeno em si.

A violência tem seu nascedouro junto com a própria humanidade, pois a mesma é fruto do próprio indivíduo. $\mathrm{O}$ risco da violência, mesmo quando não empregada dentro de uma concepção política extremista, é de os meios se tornarem o fim, pois: “[...] A prática da violência como toda ação, transforma o mundo, mas a transformação mais provável é em um mundo mais violento" (ARENDT, 1994, p. 04).

Portanto, a violência não é um fenômeno natural, intrínseco, caracterizado por um processo histórico de luta pela sobrevivência do indivíduo. Esse fenômeno nada mais é que os fins de um processo político, da luta pelo poder entre os indivíduos que vivem organizados em sociedade. Partindo do pressuposto que, toda política é uma luta pelo poder e que: “[...] o tipo de poder mais definitivo é a violência. [...] não existe então nenhum poder maior do que aquele que provém do cano de uma arma, e seria difícil dizer de que maneira a ordem dada por um policial é diferente daquela dada por um bandido armado" (ARENDE, 1994, p. 22-23).

A partir da lógica traçada pela autora supracitada subentende-se que, as instituições políticas são manifestações e concretizações do poder, estratificadas ou não, que sofrem metamorfoses, e assim que o poder emanado do povo para de apoiá-las seu poder cessa, independentemente de qual seja a forma de governo e da sua estrutura (monarquia, ditadura e democracia), outra forma surge em seu lugar, de modo que é mera ilusão imaginar que um:

[...] governo da maioria funciona apenas em uma democracia [...] o rei, que é apenas um indivíduo solitário, tem muito maior necessidade do apoio da Sociedade em geral do que qualquer outra forma de governo. Até mesmo o tirano, aquele que governa contra todos, necessita de quem o ajude a perpetrar a violência, ainda que sejam estas pessoas pouco numerosas (AREND, 1994, p. 24).

Para Arendt (1994) a violência está ligada à concepção de: (1) poder, (2) força e (3) autoridade, sinônimos, utilizados para indicar os meios pelos quais os indivíduos governam seus semelhantes, o qual permanecerá enquanto esse grupo se mantiver unido. Traçando-se uma correlação com o entendimento Weberiano é possível afirmar que os mesmos se assemelham, pois, o entendimento desse último é de que as associações políticas são nada menos que relações de dominação do ser humano sobre ele mesmo, apoiadas por meio da coação. Sendo assim, para que o Estado se mantenha, de acordo com Weber (1999, p. 524): "[...] as pessoas dominadas têm que, necessariamente, submeterem-se à autoridade invocada pelas que dominam em um dado momento".

Portanto, o Estado é um instrumento de violência organizada, que atende a um interesse geral, usado para barrar ou frear os interesses privados, em prol do interesse público (WEBER, 
1999). Dessa forma, entende-se que a violência em sua forma primária, tem seu nascedouro nas diferentes facetas do poder que emanada da sociedade, de forma peculiar dependendo de cada estrutura e do seu contexto sócio-histórico-cultural. Dessa forma, as diversas facetas da violência nada mais são que espelhos que refletem as transformações estruturais do poder dominante da sociedade.

No entanto, devido as transformações socioculturais e políticas ocorridas na sociedade contemporânea, advindas da passagem do modelo econômico (mercantilista), e político (absolutista), para o sistema capitalista (concorrencial, e posteriormente, monopolista), e de Estado (ditatoriais ou não), acarretou quase que, concomitantemente, à estratificação das formas de dominação, de poder e consequentemente da violência, para além da concepção teórica defendida por Weber (1999) e Arendt (1994). Todavia, essas transformações, essencialmente de ordem socioeconômica e cultural não eliminaram a presença de "circuitos primitivos de violência ", inseridos no seio político dos Estados-Nação, muito pelo contrário, esses são apenas novos circuitos de poder e violência, que surgem no âmago das sociedades apresentando-se pelos mais diversos formatos.

Essas novas formas de violência, segundo Iamamoto (2012) só podem ser compreendidas dentro do contexto da luta de classes do modelo econômico, social e cultural vigente. No caso, o modelo neoliberal que apresenta a solução para o fenômeno violência a partir de fragmentos da realidade, propondo o reforço em políticas públicas na segurança e na área da educação.

Vale recordar que, os teóricos neoliberais defendem que o fenômeno violência é gerado pela desigualdade social, sendo assim, esse problema deve-se à falta de igualdade de oportunidades entre os indivíduos "livres", os quais, a partir de seus dotes pessoais, podem emanciparem-se de forma democrática por meio da livre concorrência.

A teoria neoliberal defende que, as formas de violência, para além do circuito primário, deve-se ao fato das pessoas não estarem capacitadas para enfrentar tal lógica capitalista ancorada nos pressupostos de Smith (1984), a partir da "mão invisível".

Resumidamente, a resolução para o problema da violência, segundo a cartilha neoliberal, deve se dar através de investimentos em educação. Uma vez que, numa economia concorrencial, onde cada indivíduo busca seus próprios interesses pode resultar numa melhoria do bem comum. Para Smith (1984), há um mecanismo natural no mercado que distribui socialmente, os ganhos individuais. Chama-se à atenção para o fato de tal justificativa se ancorar no pressuposto que os agentes econômicos possuem um comportamento egoísta, eximindo-os assim da responsabilidade pelos enormes problemas que esse fenômeno causa à sociedade. A partir desses pressupostos, os liberais mais radicais, se utilizaram dessa analogia para reforçar a defesa do livre mercado e do modelo de Estado Mínimo, uma vez que, por meio da "mão invisível" é possível chegar a uma resolução dos problemas socioeconômicos, competindo ao Estado apenas garantir a ordem e a justiça.

Todavia, contrapondo os defensores da teoria supracitada Castel (1998) argumenta que, a mesma não é cabível para a resolução dos problemas sociais, uma vez que, para além do "exército de reserva ${ }^{2}$ " na sociedade contemporânea existe um contingente de indivíduos "moribundos" que estão à deriva e que, devido a tal realidade o fenômeno violência surge mesmo sem existir um projeto. Dessa forma, a violência pode se tornar um problema de difícil controle, tendo em vista que, não existe algo específico para ser negociado. Nas palavras do autor esse fenômeno surge contra:

\footnotetext{
${ }^{2}$ Entendido como um fato intrínseco a todo modelo de sociedade baseada do modo de produção capitalista. De modo que, a população de pessoas capacitadas e disponíveis para o mercado de trabalho proporcionam a acumulação do capital, uma vez que, essa mão de obra pode substituir os sujeitos empregados. Assim, a partir da oferta e demanda por mão de obra, os proprietários dos meios de produção possuem o controle sobre os salários, uma vez que, existe uma superpopulação disposta a aceitar um trabalho pelo valor igual ou menor oferecido pelo mercado (MARX, 1987).
} 
[...] sinais exteriores de uma riqueza insolente para os carentes (atos de delinquência, pilhagens de supermercados, destruições ostensivas de carro, etc). Mas ninguém pode dizer, sobretudo se agravar ou simplesmente se "mantiver", que tais manifestações não se multiplicarão até o ponto de se tornarem intoleráveis, desembocando não em uma "Grande Noite", mas em numerosas noites violentas durante as quais a miséria do mundo mostraria a face oculta de seu desespero (CASTEL, 1998, p. 568).

Resumidamente, Castel (1998) defende que existe um contingente populacional, tidos pela sociedade como "vagabundos", que por não conseguem mais vender sua força de trabalho, tendo sidos despojados de tudo, de suas moradias e de qualquer meio de auferirem seu próprio sustento, pois não estão mais aptos para o trabalho, perpassando assim o conceito de exército de reserva identificado por Marx (1987), principalmente, nos períodos que compreendem a Primeira (século XVIII) e a Segunda Revolução Industrial (século XIX).

\subsection{Pressupostos teóricos acerca da vulnerabilidade \& risco social}

Os conceitos de vulnerabilidade e risco social são distintos, todavia, estão intrinsecamente relacionados. Segundo Janczura (2012), o risco social está relacionado ao perigo iminente, com potencialidade de dano, à vida ou não, devido às condições fragilizadas em que se encontram os indivíduos e/ou famílias; já a vulnerabilidade social, está relacionada a ideia de suscetibilidade, portanto, a uma situação que pode acarretar em uma situação de risco social para as pessoas. Segundo elucida o mesmo autor, o risco: "[...] implica não somente na iminência imediata de um perigo, mas também a possibilidade de, num futuro próximo, ocorrer uma perda de qualidade de vida pela ausência de ação preventiva [...] para que se reduza significativamente o risco, ou que ele deixe de existir" (IDEM, 2012, p. 306).

Portanto, subentende-se que, vulnerabilidade social está atrelada à exposição a riscos e baixa capacidade material e simbólica para que as pessoas possam enfrentar tal realidade. Portanto, a vulnerabilidade, anteveem a situação de risco social, uma vez que, está condicionada a carência de equipamentos públicos de proteção social, capazes de oferecerem a esses indivíduos condições para que possam enfrentar satisfazer suas necessidades básicas, como por exemplo, o não acesso à: saúde, a educação, ao emprego, a habitação, etc.

Todavia, sabendo-se de antemão que, a vulnerabilidade e o risco social são produtos da mesma dinâmica societal, ditada pelo modelo capitalista entende-se que, o Estado possui papel central, como instituição capaz de criar mecanismos, por meio de políticas públicas, para que os indivíduos, em tais situações, permaneçam nesse contexto o menor tempo possível, pois caso nada seja feito corre-se o risco de existir um efeito "cascata", capaz de desencadear uma série de problemas, como por exemplo, as várias facetas da violência.

A afirmativa supracitada é evidenciada nas ponderações de Iamamoto (1982) acerca do problema, dado que para a autora, a vulnerabilidade social nada mais é que uma das formas materializadas das expressões da questão social que se refere a todo invólucro das desigualdades da sociedade, que podem ser evidenciadas nas determinações econômicas, políticas e culturais que impactam as classes sociais.

Salienta-se que, assim como Iamamoto (1982), Castel (1998) defende que, nos países em desenvolvimento, no caso o Brasil, a vulnerabilidade social está atrelada à ideia de risco frente ao desemprego, à precariedade do trabalho, à pobreza e à falta de proteção social. Além disso, é importante recordar que a sociedade é ditada pelo consumo que: 
[...] comanda um sistema de relações entre as categorias sociais, segundo o qual os objetos possuídos são os marcadores das posições sociais, indicadores de uma classificação. Os sujeitos põem em jogo aí não sua aparência, mas sua identidade. Se manifestando através do que consomem o seu lugar no conjunto social (CASTEL, 1998, p. 475).

Diante da análise dos conceitos em questão, observa-se que o conceito de vulnerabilidade está atrelado à suscetibilidade das pessoas passarem para uma circunstância de agravamento das condições mínimas de sobrevivência. Já a situação de risco social pode-se associar ao contingente populacional de "moribundos" mencionado por Castel (1998), que engloba todos os indivíduos com possibilidades remotas de voltarem a serem inseridos no modelo societal, justamente por, existir um "exército de reserva" que se encontra em situação de vulnerabilidade social à espreita de uma oportunidade de retornarem ao mercado de trabalho e assim, ao convívio social, nos moldes que a sociedade capitalista está alicerçada.

Cabe destacar que, as ponderações de Iamamoto (1982) e de Castel (1998), são passíveis de serem correlacionadas com o entendimento acerca da existência de três níveis ${ }^{3}$, ou melhor dizendo, indicadores de privação trabalhados por Clavel (2004) que podem levar da situação de vulnerabilidade para um estágio entendido pelo mesmo autor como de exclusão social, quais sejam:

[...] habitação, educação, emprego, condições de trabalho, rendimentos, saúde, lazer, redes de relações, equipamentos e bens de consumo, hábitos alimentares, dentre outros. Demonstrando que a exclusão social engloba aspectos multidimensional e multiforme da pobreza, mas que não se resume a simples falta de recursos materiais, pois adentram no: campo jurídico, habitação, econômico, família rupturas e perdas de relação social, saúde, escola, serviços públicos, ideologia, lutas sociais (CLAVEL, 2004, p. 25-51).

Portanto, perante instabilidades socioeconômicas, multidimensionais é possível afirmar que existe um contingente populacional que frente ao desemprego, pobreza e insegurança já deixaram as zonas de "integração, precariedade e pobreza" e estão estagnados em situação de exclusão social, que "[...] com o passar do tempo aumenta a probabilidade de não saírem mais" Clavel (2004, p. 157), definido por Castel (1998) como sujeitos "moribundos" objetos de estigmas por parte das diversas formas de distinção, dos indivíduos no estrato societal.

Quanto a possíveis caminhos para a resolução do problema Souza (2006) defende que, se fazem necessárias políticas públicas, construídas com base na multidimensionalidade que a temática envolve devendo ser compreendidas a partir da dimensão dos campos: da Sociologia, da Ciência Política e da Economia, uma vez que, as políticas públicas:

[...] repercutem na economia e nas sociedades, daí por que qualquer teoria da política pública precisa também explicar as inter-relações entre Estado, política, economia e sociedade. Tal é também a razão pela qual pesquisadores de tantas disciplinas - Economia, Ciência Política, Sociologia, Antropologia, Geografia, Planejamento, Gestão e Ciências Sociais Aplicadas - partilham um interesse comum na área e tem contribuído para avanços teóricos e empíricos (SOUZA, 2006, p. 25).

É importante ter em mente que, para uma medida ser concebida, implantada e/ou analisada, deve-se levar em consideração a realidade social que a mesma está e/ou será, cita-se como por

${ }^{3}$ Clavel (2004) entende que existem três zonas antes das pessoas entrarem em situação de exclusão social, quais sejam: "integração, precariedade e pobreza". 
exemplo: o momento político, as condições socioeconômicas, bem como, o modelo político vigente no País (RODRIGUES, 2008b).

Sendo assim, quando mencionamos "políticas públicas", devemos considerar os fatores internos e externos seja a nível micro ou macro-social (bairros, municípios, Estados e o País), uma vez que, as mesmas afetam de forma direta e indireta todos os actores sociais devido aos mais diversos conflitos de interesses inerentes a qualquer decisão tomada de âmbito político (RODRIGUES, 2008b).

A afirmativa supracitada é evidenciada nas ponderações de Lowi (1964; 1972 apud Souza, 2006, p. 30), ao elucidar que: “[...] a política pública faz a política, que irá encontrar diferentes formas de apoio e rejeição em torno de sua decisão".

Além disso, os mesmos autores elucidam que as medidas podem ser divididas em quatro segmentos, quais sejam: 1) Distributivas, geram mais impactos individuais do que universais, uma vez que, privilegiam certos grupos sociais ou regiões em detrimento do todo; 2) Regulatórias, mais visíveis ao público, pois estão ligadas a tramites burocráticos, políticos e grupos de interesse; 3 ) Redistributivas, impõem perdas e ganhos sociais para determinados setores da sociedade, como por exemplo, sistema tributário, previdenciário, etc.; e 4) políticas constitutivas, cujo a finalidade é distribuir responsabilidades entre os entes da unidade federativa (municípios, Estados e o Governo Federal).

\section{PROCEDIMENTOS METODOLÓGICOS}

A metodologia utilizada foi exploratória-descritiva com enfoque quantitativo. Segundo Demo (2008), o alicerce de sustentação da pesquisa social é o desejo crescente de conhecer melhor a sociedade, sobretudo as facetas não lineares, desse modo, esse tipo de pesquisa, possui: "'[...] seus esforços direcionados para a realidade social, sobretudo suas faces qualitativas. Ainda assim, não há de ser negado suas faces quantitativas, mas como Ciência Social o foco está no mundo das qualidades" (2008 apud DEMO, 2004b, p. 67).

Vale recordar que, para Minayo (2006, p.76) “[...] o arcabouço qualitativo é o que melhor se enquadra a estudos e situações particulares, grupos específicos e universos simbólicos". No mesmo sentido Gil (1999, p. 31) elucida que, estudos na área das Ciências Sociais: "[...] os fatos não podem ser considerados fora de um contexto social, político e econômico".

As técnicas e instrumentos da coleta de dados ocorreram através de observações, por meio de entrevistas e de um questionário sociodemográfico, os quais possibilitaram capturar os olhares e os significados, expressos por meio das falas dos sujeitos. Vale ressaltar que, as entrevistas, só foram possíveis devido a intermediação da Associação Sol da Manhã, a qual as 5 famílias entrevistadas, vitimadas pela violência em seu maior grau fazem parte.

A metodologia também levou em consideração, os princípios do Código de Ética Profissional do (a) assistente social, especialmente no que concerne ao sigilo profissional, tratado em seu Capítulo V, Artigo 16. ${ }^{\circ}$, no qual está disposto que: “[...] o sigilo protegerá o usuário em tudo aquilo de que o Assistente Social tome conhecimento, como decorrência do exercício da atividade profissional" (CFESS, 1993, p.18).

Desse modo, foi respeitado o sigilo dos participantes que tiveram suas identidades preservadas, fazendo-se uso de nomenclaturas (família A, B, C e assim por diante), bem como foram dirimidas dúvidas acerca do estudo através da leitura do Termo de Consentimento Livre e Esclarecido (TCLE) que no segundo momento foram assinadas pelos sujeitos que aceitaram participar do estudo. 


\subsection{O campo da pesquisa}

A capital do Estado do Ceará, é considerada pelo Instituto Brasileiro de Geografia e Estatística (IBGE) uma metrópole. Portanto, uma das Regiões de Influência das Cidades (REGIC) ${ }^{4}$, devido sua elevada atração de empresas e órgãos públicos e, por consequência, devido a oferta de bens e serviços (educação, saúde, trabalho, universidade, etc) que leva ao deslocamento de populações de outros municípios ou até mesmo regiões para essa cidade (IBGE, s/db).

De acordo com o último Censo demográfico realizado no ano de 2010, pelo IBGE, a cidade de Fortaleza possui 2.452.185 milhões de habitantes, dispostos por uma área territorial de 314,930 $\mathrm{Km}^{2}$, com uma densidade demográfica de 7.786,52 (hab/ $\left.\mathrm{km}^{2}\right)$, um Índice de Desenvolvimento Humano $(\mathrm{IDH})^{5}$ de 0,754 e com uma renda per capita média no valor de $\mathrm{R} \$ 846,36$. Além disso, vale ressaltar que, muito embora a capital cearense seja detentora do:

[...] $9^{\circ}$ maior PIB entre os municípios brasileiros, a ausência de políticas públicas que promovam a inclusão social e produtiva do grande contingente populacional em situação de miséria e condições precárias de moradia ao longo de décadas gerou grande passivo social. A capital cearense figura como a $5^{\text {a }}$ cidade mais desigual do mundo no relatório das Nações Unidas "State of the World Cities 2010/2011: Bridging the Urban Divide" (IPLANFOR, 2015, p. 91).

Desse modo, muito embora a cidade apresente um IDH maior que a média brasileira $(0,699)$, situando-se no grupo considerado pelo Programa das Nações Unidas para o Desenvolvimento (PNUD) como de desenvolvimento alto, a tamanha desigualdade social é observada por inúmeros indicadores, como por exemplo, a renda, uma vez que, $36,9 \%$ da sua população alcança uma renda nominal per capita mensal de até 1/2 salário mínimo (IBGE, s/db).

Acerca da discrepância de renda entre os diferentes extratos sociais existente na cidade destaca-se que, mesmo com $36,9 \%$ de sua população vivendo com apenas $1 / 2$ salário mínimo, para o Ministério do Desenvolvimento Social e Combate à Fome (MDS), apenas parte dessas pessoas pode serem consideradas pobres ou extremamente pobres. Pois, segundo os critérios do mesmo órgão, um indivíduo se encontra nessa situação caso possua uma renda per capita mensal, respectivamente: igual ou superior a $\mathrm{R} \$ 70$ até $\mathrm{R} \$ 140,00$; e famílias que aufere renda nominal mensal igual ou inferior a $\mathrm{R} \$ 70$ per capita (BRASIL, 2014).

A respeito da comunidade estudada, sua história teve início nos anos de 1990, quando foi construído um loteamento, pela Companhia de Habitação do Ceará (COHAB) com o objetivo de atender a carência habitacional de 1.246 famílias, que se encontravam vivendo em barracos no bairro Tancredo Neves. De acordo com as palavras da presidente da Associação Sol da Manhã que também é uma das representantes daquela comunidade, o bairro Barroso:

[...] só foi criado a partir de um acampamento feito de barracos de lona, com 1.246 famílias, acampadas no bairro Tancredo Neves. Isso após 5 anos de muita luta, o então Governador da época Ciro Gomes autorizou o financiamento e a execução do programa habitacional na modalidade de Mutirão (Entrevista realizada em 17/04/2015).

\footnotetext{
${ }^{4}$ As REGIC's definem a hierarquia dos centros urbanos brasileiros e delimita as regiões de influência a eles associados dividida em 5níveis, quais sejam: Metrópoles, Capitais Regionais, Centros Sub-Regionais, Centros de Zona e Centros Locais (IBGE, s/db).

${ }^{5} \mathrm{O}$ IDH é uma medida utilizada para avaliar o desenvolvimento humano levando em consideração a expectativa de vida; à educação e o padrão de vida medido pela Renda Nacional Bruta (RNB) per capita. O Índice varia de 0 a 1 . Quanto mais próximo de 1 melhor maior é o nível de desenvolvimento humano, e quanto mais próximo de 0 pior. Ressalta-se que, o Programa das Nações Unidas para o Desenvolvimento (PNUD), divide o IDH em 4 grupos, quais sejam: 1) Muito alto D.H; 2) Alto D.H; 3) Médio D.H; e4) Baixo D.H. (Fortaleza 2040, 2015); (PNUD, s/db).
} 
Salienta-se que, mesmo tendo sido construído com a finalidade de atender as 1.246 famílias, no ano de 2010, a comunidade, já contava com 29.847 mil moradores, distribuídos em uma área de $3,68 \mathrm{~km}^{2}$, verificando-se assim, uma superpopulação distribuída numa pequena região geográfica, ou em outras palavras, numa densa gama de pessoas vivendo na mesma residência (IPLANFOR, 2015).

Segundo o último censo realizado no Brasil, em 2010, a comunidade do Barroso, possui 8,94\%, ou seja, 2.669 indivíduos inseridos nos critérios do MDS, portanto, considerados em situação de extrema pobreza, conforme pode ser observado no rendimento nominal médio mensal dos bairros da cidade (IPLANFOR, 2015).

Concomitantemente correlacionando-se o IDH médio da capital com alguns bairros da cidade chama-se à atenção, para a elevada discrepância entre os mesmos. Ou seja, o nível de desigualdade social encontra-se distribuído por mais de 50\% dos bairros, uma vez que, de acordo com a Secretaria Municipal de Desenvolvimento Econômico (SMDE, s/db) "[...] 28 bairros encontram-se com IDH abaixo de 0,25, o que corresponde a $24 \%$ dos bairros de Fortaleza, e considerando os bairros com IDH inferior a 0,5 , este número corresponde a $76 \%$ dos bairros".

Outro dado que cabe destacar, a partir de um olhar atento na legenda da Figura 1, refere-se à quantidade elevada de bairros que estão, quando comparados com os indicadores da PNUD, situados no nível de desenvolvimento humano baixo. Pois, somando-se os bairros que estão na cor vermelha e laranja da Figura 2, verifica-se que esses totalizam 62 comunidades.

De forma resumida é possível afirmar que, mais de 50\% dos bairros da cidade, ou 59,66\% da população (1.463.071 de pessoas), vive sob condições de desenvolvimento humano equiparáveis as últimas 15 posições dos países (IDH igual ou inferior a 0,350) que compõem o ranking do PNUD de 2010, quais sejam: Etiópia (0.328); Serra Leoa (0.317); República Centro-Africana (0.315); Mali (0.309); Burkina Fasso (0.305); Libéria(0.300); Chade (0.295); Guiné-Bissau (0.289); Moçambique (0.284); Burundi (0.282); Níger (0.261); República Democrática do Congo (0.239); e Zimbábue (0.140) (PREFEITURA MUNICIPAL DE FORTALEZA, 2010, s/n.); (PNUD, s/db).

No caso do bairro Barroso, segundo o Instituto de Planejamento de Fortaleza (IPLANFOR) e disposto na Figura 1, a comunidade possui um IDH de 0,186, situa-se na $107^{\text {a }}$ posição dentre os 119 bairros que compõem a cidade. A partir dessa realidade verifica-se que a localidade faz parte das regiões da capital que possui uma das maiores incidências de pessoas vivendo em situação de extrema pobreza, inclusive, com um IDH só é maior que o Zimbábue $(0,140)$, último colocado entre os 169 países analisados pelo PNUD, no ano de 2010 (IPLANFOR, 2015); (PNUD, s/db). 


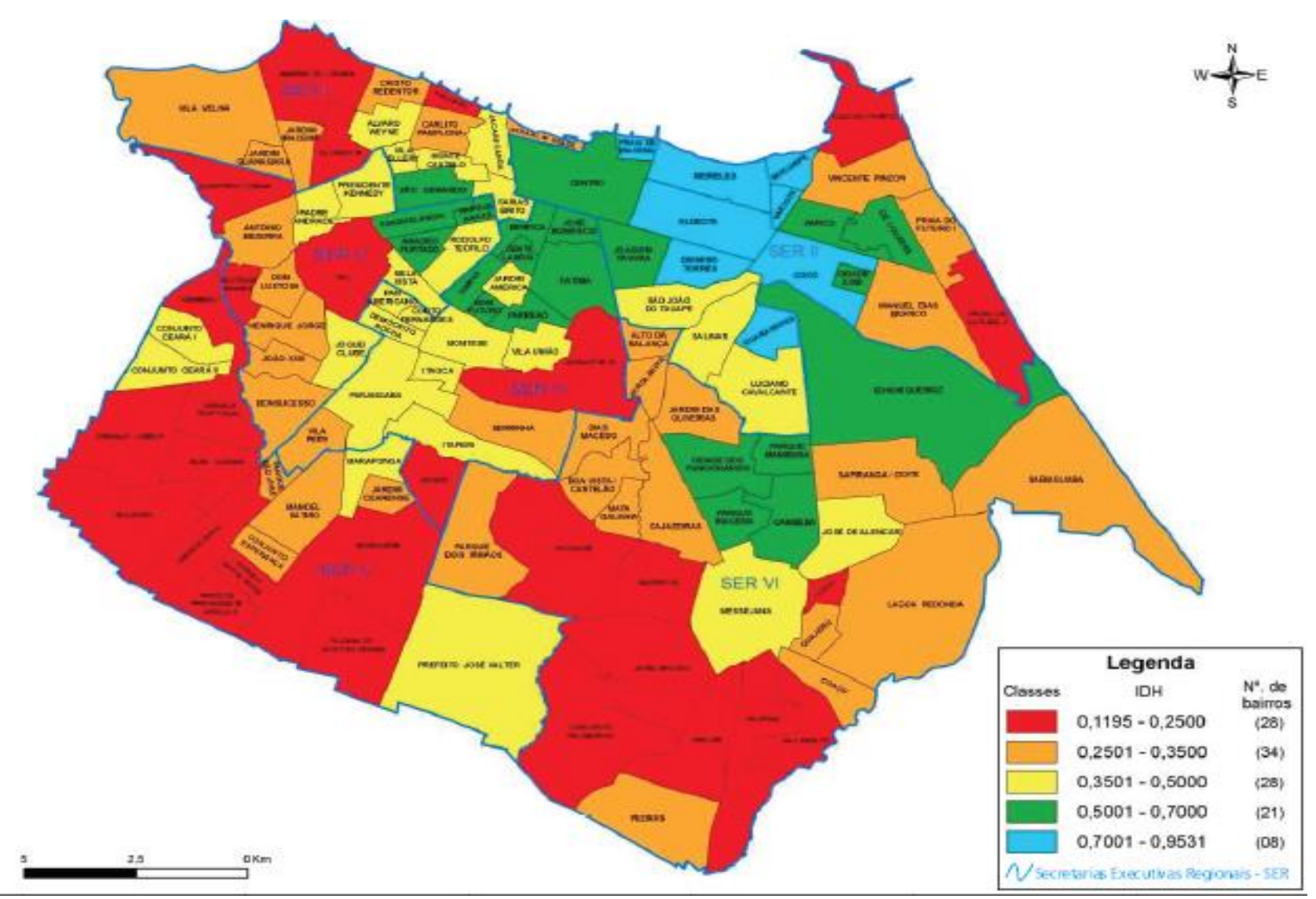

Figura 1. IDH dos bairros de Fortaleza em 2010. Fonte: (SECRETARIA DE DESENVOLVIMENTO ECONÓMICO DA PREFEITURA MUNICIPAL DE FORTALEZA, 2010, s/n.).

O contexto de desigualdade social observado na comunidade do Barroso, fica ainda mais evidente quando se compara a renda média do bairro mais rico da cidade (Meireles) com o mais pobre (Conjunto Palmeiras), uma vez que, a renda do primeiro é 15,3 vezes maior que a remuneração média auferida pelos sujeitos residentes na comunidade mais carente da cidade (IPLANFOR, 2015). Analisando-se esse problema que faz parte da questão social é possível afirmar ainda que:

[...] a média das rendas dos dez mais ricos é 8,6 vezes maior que a média das rendas dos dez bairros mais pobres. [...] $7 \%$ da população total de Fortaleza que vive nos dez bairros mais ricos se apropriam de $26 \%$ da renda pessoal total da cidade. Por outro lado, os 44 bairros de menor renda, que juntos somam quase metade da população total de Fortaleza (49\%), apropriam-se dos mesmos 26\% da renda pessoal total (IPLANFOR, 2015, p. 95).

Além disso, chama-se à atenção ainda para o fato dos dois bairros com os maiores IDH's da cidade, Meireles $(0,935)$ e Aldeota $(0,866)$, quando somados os residentes nos mesmos totalizam apenas 79.343 mil indivíduos. Ou seja, apenas um número irrisório de indivíduos possui acesso a condições de vida, portanto, índices de desenvolvimento equiparados, respectivamente a Noruega $(0,938)$ e Dinamarca $(0,866)$, inclusive, enquadrão-se no índice de desenvolvimento humano mais alto elaborado pela PNUD (s/db) e IPLANFOR (2015).

A partir da discrepância existente no IDH, entre várias localidades na mesma cidade é possível verificar a profundidade da estratificação societal supracitada, pois os 8 bairros com melhor IDH do município, quando somada sua população (146.033 mil indivíduos), representa apenas $5,95 \%$, do total das pessoas que residem na capital. Fato esse que contrasta outra realidade 
da metrópole uma vez que, a mesma possui 134 mil pessoas vivendo na extrema pobreza, o equivalente a 5,5\% do total de sua população. Sendo que, desse universo 2.669 ou $8,94 \%$ são moradores do bairro Barroso (IPLANFOR, 2015).

Tais disparidades sociais entre a população de uma determinada região, que emergem através dos números do $\mathrm{IDH}$, corroboram para o aumento da violência comprovando assim, sua relação intrínseca com as condições de vida desse contingente populacional que "sobrevive" sob circunstancias onde prevalece uma sobreposição de fatores como: baixa renda, desemprego, baixo nível de escolaridade, inacessibilidade à saúde e ao lazer que traduzem-se em situações de vulnerabilidade social, risco social e, em elevados números de violência (homicídios), conforme ilustrado na Figura 3.

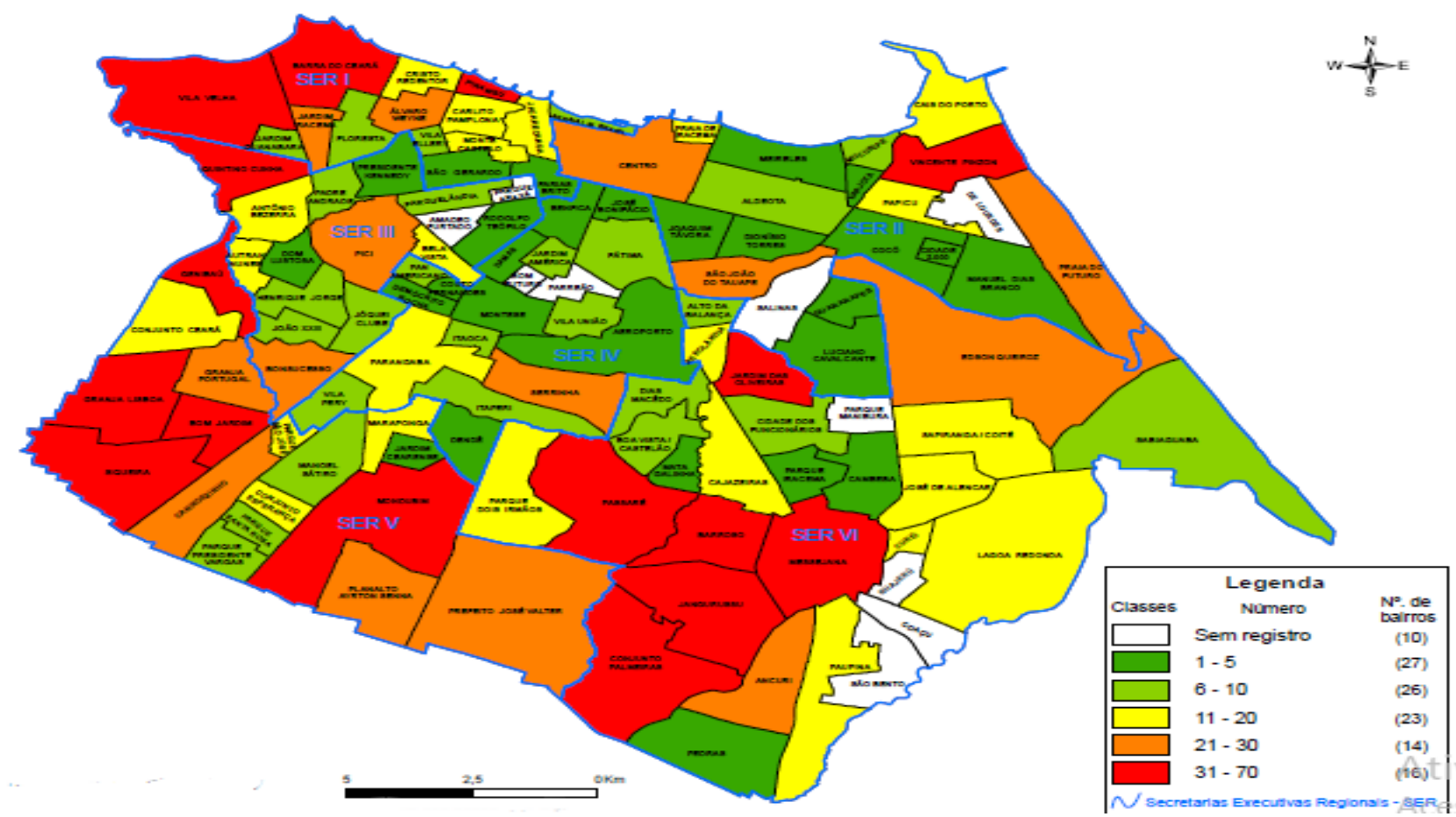

Figura 3. Distribuição de homicídios por bairro de Fortaleza. Fonte: (IPLANFOR, 2015).

Conforme pode ser observado, no ano de 2010, apenas 10 bairros não tiveram registro de homicídio em Fortaleza, quais sejam: Amadeu Furtado, Bom Futuro, Parreão, Parque Manibura, Guajerú, Coaçu, São Bento, Salinas, Lourdes e Parque Araxá. Além disso, verifica-se que o Barroso integra os 16 bairros onde as regionais tiveram os maiores registros de homicídios.

\section{RESULTADOS E DISCUSSÃO}

As características gerais dos (as) responsáveis pela família teve como objetivo compreender a o perfil sociodemográfico do agregado familiar. Para isso, foi realizada uma série de indagações com o responsável pela família que tiveram seus filhos vitimados pela violência cuja as informações estão dispostas nos Quadros 1 e 2. 


\begin{tabular}{llllll}
\hline Informações & Família A & Família B & Família C & Família D & Família E \\
\hline Parentesco & Mãe & Mãe & Mãe & Mãe & Mãe \\
\hline Idade & 33 & 36 & 35 & 46 & 44 \\
\hline Cor & Parda & Branca & Parda & Parda & Parda \\
\hline Estado civil & Solteira & Solteira & Separada & Solteira & Solteira \\
\hline Escolaridade & $\begin{array}{l}12^{\circ} \text { ano } \\
\text { incompleto }\end{array}$ & $9^{\circ}$ ano & $12^{\circ}$ ano & $9^{\circ}$ ano & $9^{\circ}$ ano \\
incompleto & incompleto & incompleto & completo \\
\hline Estudando & Não & Não & Não & Não & Não \\
\hline Ocupação & Vendedora & Empregada & Auxiliar & Salgadeira & Costureira \\
autônoma & doméstica & geral & Não & Não \\
\hline $\begin{array}{l}\text { Vínculo } \\
\text { empregatício }\end{array}$ & Não & Não & Não & Sim & Sim \\
\hline $\begin{array}{l}\text { Recebe benefício } \\
\text { do PBF }\end{array}$ & Sim & Sim & Sim & Sim & \\
\hline \begin{tabular}{l} 
Qim \\
\hline
\end{tabular}
\end{tabular}

Quadro 1. Características gerais dos (as) responsáveis pela família. Fonte: Pesquisa direta (2015).

De acordo com os dados contidos no Quadro 1 podemos afirmar que as responsáveis pelas famílias vitimadas pela violência são do gênero feminino, predominantemente da cor parda, não concluíram o $12^{\circ}$ ano, chefes ou representantes de famílias monoparentais e não possuem vínculo empregatício (auferem renda por meio de trabalhos informais e do PBF). Desse modo, observa-se que existem inúmeros fatores que contribuem para as famílias pesquisadas estarem em situação de vulnerabilidade social.

Segundo Diniz (2002, p. 11), a família monoparental ou unilinear desvincula-se: “[...] da ideia de um casal relacionado com seus filhos, pois estes vivem apenas com um dos seus genitores, em razão de viuvez, separação judicial, divórcio, adoção unilateral, não reconhecimento de sua filiação pelo outro genitor, produção independente, etc".

Segundo Carvalho (1998, p. 85), tal realidade deve-se, principalmente, a segregação da mulher aos:

[...] piores postos de trabalho, à pior remuneração e à ausência de mobilidade social nas atividades ditas femininas. [...] vinculada as atividades informais [...] a composição do domicilio parece ser um fator preponderante. A chefia feminina parece estar associada a domicílios menores. [...] na maioria das vezes, o único membro adulto [...] o que diminuí as chances de outros rendimentos reforçarem o orçamento doméstico. [...] assume as funções domésticas de um grupo familiar. Isso dificulta a conjugação entre trabalho remunerado, cuidado com os filhos e atividades domésticas. Devido a essas dificuldades [...] não tem outra escolha a não ser vincular-se a trabalhos mais mal remunerados [...] em sua própria casa ou nas redondezas [...] de tempo parcial ou intermitentes. [...] grande parte decorrentes de gravidezes precoces e instabilidade familiar, o que tende a contribuir para a reprodução da pobreza de geração a geração.

Resumidamente, é possível afirmar que os achados da pesquisa vêm de encontro com a explanação colocada por Carvalho (1998) uma vez que, as histórias de vida reladas pelas entrevistadas remetem a esses fatores, conforme pode ser observado nos Quadros 1 e 2, esses indivíduos possuem dificuldades em prover sua subsistência e de seus filhos, remetendo as mesmas para situações de vulnerabilidade e, até mesmo de risco social, conforme observado, inclusive, nas condições de moradia, abaixo. 


\begin{tabular}{|c|c|c|c|c|c|}
\hline Habitação & Família A & Família B & Família C & Família D & Família E \\
\hline $\begin{array}{l}\text { Condição da } \\
\text { moradia }\end{array}$ & Ocupada & Cedida & Ocupada & Cedida & Ocupada \\
\hline Coabitação & Sim & Sim & Não & Sim & Não \\
\hline $\begin{array}{l}\text { Procedência } \\
\text { da Família }\end{array}$ & Fortaleza & Interior & Fortaleza & Fortaleza & Fortaleza \\
\hline $\begin{array}{l}\text { Tipologia da } \\
\text { construção }\end{array}$ & Alvenaria & Lona & Alvenaria & Alvenaria & Alvenaria \\
\hline $\begin{array}{l}\mathrm{N}^{\mathrm{o}} \text { de } \\
\text { residentes }\end{array}$ & 5 & 5 & 6 & 8 & 4 \\
\hline $\begin{array}{l}\text { Quantidade de } \\
\text { cômodos }\end{array}$ & 3 & 1 & 2 & 2 & 3 \\
\hline Área de risco & Sim & Sim & Não & Sim & Sim \\
\hline Rede de água & Sim & Não & Sim & Sim & Sim \\
\hline $\begin{array}{l}\text { Coleta de } \\
\text { esgoto }\end{array}$ & Não & Não & Não & Não & Não \\
\hline Rede elétrica & $\begin{array}{l}\text { Sim } \\
\text { clandestina }\end{array}$ & $\begin{array}{l}\text { Sim } \\
\text { clandestina }\end{array}$ & $\begin{array}{l}\text { Sim } \\
\text { oficial }\end{array}$ & $\begin{array}{l}\text { Sim } \\
\text { clandestina }\end{array}$ & Sim oficial \\
\hline $\begin{array}{l}\text { Tipo de } \\
\text { pavimentação }\end{array}$ & Paralelepípedo & Piçarra & Piçarra & Piçarra & Paralelepípedo \\
\hline $\begin{array}{l}\text { Destinação do } \\
\text { lixo }\end{array}$ & Contêiner & $\begin{array}{l}\text { Terreno } \\
\text { baldio }\end{array}$ & Contêiner & Contêiner & Contêiner \\
\hline
\end{tabular}

Conforme pode ser observado, o perfil sociodemográfico das famílias dos jovens assassinados também remete a vulnerabilidade e ao risco social da infraestrutura do imóvel, uma vez que, abarca: condições precárias da moradia, número elevado de residentes por cômodo, o tipo da construção, o não acesso ao saneamento básico, ao abastecimento de água, a rede elétrica, as condições da rua e a destinação do lixo.

Como podemos observar no Quadro 2, às características dos domicílios das famílias que tiveram seus jovens assassinados são: ocupados ou cedidos, construídos de forma irregular, vivendo na condição de coabitação e residências de alvenaria, sendo procedentes da mesma cidade, com exceção de uma família que veio do interior do Estado.

No tocante ao número de moradores por residência, verificou-se uma média de 5,6 indivíduos $^{6}$, por domicílio. Ressalta-se que, para o mesmo bairro, segundo o último Censo, a média de moradores por domicílio era de 3,6.

Desse modo, tal dado demonstra existir uma superlotação de indivíduos vivendo no mesmo domicílio, uma vez que, quando correlacionados ao número de pessoas residentes, verifica-se uma que a taxa média de indivíduos por residência está acima da média do município, pois a quantidade média de indivíduos por residência observada foi de 5,6, quase o dobro da média da cidade de Fortaleza, 3,43 indivíduos por residência. Sendo assim, essa realidade encontrada por si só, é

\footnotetext{
${ }^{6}$ Para se chegar à média aritmética de indivíduos residentes por unidade habitacional somamos o total de habitantes por residência e dividimos pelo número de famílias, no caso cinco, chegamos assim, a uma média de 5,6 indivíduos por unidade habitacional, como segue: $(5+5+6+8+4) / 5=5,6$.
} 
preocupante, haja vista que, a quantidade média de cômodos ${ }^{7}$ por indivíduos, 0,39 , excluindo o banheiro.

Correlacionando o contexto social encontrado, com estudiosos da temática observa-se que, tal situação indica que os espaços domésticos possuem usos múltiplos (salas e cozinhas são usadas como dormitórios), concorrendo para o stress familiar, pois leva a um desconforto psicológico e à falta de privacidade para os adultos que acaba por fomentar conflitos interpessoais (CARDIA; SHIFFER, 2002).

Quanto à rede de esgoto, o município possui uma coberta em 53,6\%, já na comunidade estudada segundo o IPECE (2012), no ano de 2010 apenas 48,72\% dos domić́lios do bairro se encontravam ligados à rede de esgoto. Todavia, tais números não dizem respeito as famílias que fizeram parte do estudo, uma vez que, nenhuma possuía coleta de esgoto.

As vias, para de deslocamento na comunidade, observou-se, no percurso até a Associação Sol da Manhã, que são em sua maioria de piçarra, com muitos buracos e de difícil acesso, realidade essa que também foi reiterada pelas famílias. No que se refere ao consumo de água no bairro, segundo o IPECE (2012), 96,15\% das residências estão ligadas à rede, no entanto, dentre as famílias pesquisadas apenas $80 \%$ destas são atendidas pela rede de água da Companhia de Água e Esgoto do Ceará (CAGECE).

Conforme pode ser observado no Quadro 3, o acesso à rede de energia elétrica muito embora de acordo com o IPECE (2012), a comunidade possui uma cobertura de 99,51\%, as famílias entrevistadas fazem parte dos $0,49 \%$, pois a maioria se utiliza de "gato", para terem energia elétrica.

A coleta de lixo, $80 \%$ das famílias possuem acesso a esse serviço público, no entanto, o bairro possui uma cobertura de 95,70\%, de acordo com o IPECE (2012), revelando assim, que parte desses indivíduos não possuem cobertura desse serviço.

De um modo geral, a partir do questionário aplicado as famílias e pela própria da presidente da Associação Sol da Manhã que reside na comunidade a 20 anos, acerca do cotidiano da comunidade percebemos que, existe um completo abandono pelo setor público, dada a "quantidade de sobreposição de carências", utilizando aqui as palavras de (CARDIA; SHIFFER, 2002, p.31).

No caso, dos jovens assassinados, no mesmo bairro, buscamos informações concretas e objetivas no que concernia ao nosso objeto de estudo, os jovens vitimados pela violência no Bairro Barroso. Para isso, indagamos aos seus familiares, no caso, suas mães, sobre as características dos mesmos, tais como: sexo, idade, ano do óbito, cor, grau de escolaridade, se estudavam quando vieram a óbito, ocupação, o motivo que os levou ao óbito e qual o tipo de arma (de fogo ou arma branca). Para tanto, podemos observar o perfil desses jovens, no Quadro 3.

\begin{tabular}{llllll}
\hline Informações & Jovem A & Jovem B & Jovem C & Jovem D & Jovem E \\
\hline Sexo & Feminino & Masculino & Masculino & Masculino & Masculino \\
\hline Idade & 15 & 16 & 16 & 16 & 18 \\
\hline Ano do Óbito & 2012 & 2013 & 2012 & 2012 & 2013 \\
\hline Cor & Parda & Branco & Pardo & Pardo & Pardo \\
\hline
\end{tabular}

\footnotetext{
${ }^{7}$ Para se chegar à média aritmética de cômodos por indivíduos somamos o número total de cômodos das cinco famílias da Tabela 3 e dividimos pela soma total de indivíduos residentes de todas as famílias da Tabela 1, como segue: $(3+1+2+2+3) / 28=0,39$.

${ }^{8}$ Expressão utilizada no Brasil, para ligação clandestina a rede de energia elétrica.

${ }^{9}$ De acordo com a entrevista, a mãe responsável da família D relatou que teve 3 de seus 7 filhos foram assassinados ao mesmo tempo. A idade dos mesmos era, respectivamente: 16, 26 e 28.
} 


\begin{tabular}{|c|c|c|c|c|c|}
\hline Escolaridade & $\begin{array}{l}9^{\circ} \text { ano } \\
\text { incompleto }\end{array}$ & $\begin{array}{l}9^{\circ} \text { ano } \\
\text { incompleto }\end{array}$ & $\begin{array}{l}9^{\circ} \text { ano } \\
\text { incompleto }\end{array}$ & $\begin{array}{l}9^{\circ} \text { ano } \\
\text { incompleto }\end{array}$ & $\begin{array}{l}9^{\circ} \text { ano } \\
\text { completo }\end{array}$ \\
\hline Estudava & Sim & Não & Não & Não & Não \\
\hline Trabalho/ocupação & Não & Não & Não & Não & Não \\
\hline Motivo do óbito & Passional & Assalto & $\begin{array}{l}\text { Tráfico de } \\
\text { drogas }\end{array}$ & Indefinido & $\begin{array}{l}\text { Tráfico de } \\
\text { drogas }\end{array}$ \\
\hline Tipo de arma & $\begin{array}{l}\text { Arma de } \\
\text { Fogo }\end{array}$ & $\begin{array}{l}\text { Arma } \\
\text { Fogo }\end{array}$ & $\begin{array}{l}\text { Arma } \\
\text { Fogo }\end{array}$ & $\begin{array}{l}\text { Arma } \\
\text { Fogo }\end{array}$ & $\begin{array}{l}\text { Arma } \\
\text { Fogo }\end{array}$ \\
\hline
\end{tabular}

Quadro 3. Dados dos jovens assassinados entre os anos de 2012 e 2013. Fonte: Pesquisa direta, 2015.

Conforme pode ser observado na Quadro 3, os jovens assassinados se deram por arma de fogo, eram majoritariamente do sexo masculino, com idade entre 15 e 18 anos, não possuíam ocupação e, existia uma defasagem escolar em relação à idade, devido à evasão escolar.

Segundo relatado pela família $\mathrm{C}$, acerca da frequência escolar: "Meu filho deixou de frequentar a escola, dizia que ia para a escola, mas já não chegava mais no destino, ficava na boca vendendo droga. Infelizmente, muitos jovens aqui pensam que ganham muito mais dinheiro vendendo droga do que estudando". (Entrevista realizada em 17/04/2015).

A razão que levou ao óbito dos jovens, a família $\mathrm{A}$, afirmou que o motivo foi passional. A família B perdeu seu filho por ter reagido a um assalto. No caso das famílias C e E o fato ocorreu por envolvimento com o tráfico de drogas e, a família $\mathrm{D}$, não quis comentar sobre o motivo levou ao assassinato de seus filhos.

Diante das informações dispostas no Quadro 3, correlacionadas com os dados da Pesquisa Nacional por Amostra de Domicílios (PNAD) ${ }^{10}$, com estudos realizados pelo IPECE (2012), com dados estatísticos da SSPDS, com dos sujeitos entrevistados, parece evidenciar que a falta de atrativos para esses jovens frequentarem a escola e, consequentemente, o envolvimento com o tráfico de drogas, pode ser umas das explicações para a alta taxa de homicídio entre os jovens na comunidade pesquisada. Portanto, evidencia-se uma relação entre tais causalidades e a vulnerabilidade social.

Cabe colocar que, à cor dos jovens assassinados, $80 \%$ de nossa amostra é da cor parda. Algo que, para muitos teóricos revela a existência de uma relação intrínseca e indissociável entre questão social e preconceito racial. A violência, a desigualdade social, a marginalização dos indivíduos, dentre outras, nos centros urbanos, é uma das expressões materializadas da questão social, demonstrando assim a situação de vulnerabilidade social em que se encontra essa população (IANNI, 2004).

Além disso, correlacionando a pesquisa com outros estudos, percebe-se que existe indícios que a taxa de homicídio entre os jovens negros é maior comparativamente com os jovens brancos, cita-se como exemplo, a pesquisa intitulada "Índice de Vulnerabilidade Juvenil à Violência e Desigualdade Racial (2014) ${ }^{11}$, realizada pelo do Ministério da Justiça em parceria com o Fórum Brasileiro de Segurança Pública, em 2012, Estado do Ceará, a taxa de homicídios entre a população jovem negra era 4 vezes maior que a mesma taxa da população branca, ou seja, entre os jovens negros eram 58 homicídios por 100 mil habitantes.

\footnotetext{
${ }^{10}$ De acordo com o Ministério da Justiça, idealizador do estudo, o Índice de Vulnerabilidade Juvenil à Violência e Desigualdade (2014, p. 12) tem como objetivo mensurar a vulnerabilidade à violência entre adolescentes e jovens de 12 a 29 anos para as 27 unidades da federação e incorporar a existência de desigualdades de raça/cor a partir do risco relativo de negros e brancos serem vítimas de homicídios.

${ }^{11}$ De acordo com PNAD, realizada pelo IBGE e divulgada em 2013, o Estado do Ceará possuía cerca de 80 mil jovens entre 15 a 17 anos fora da escola.
} 
Portanto, observa-se que, tais dados corroboram, com as afirmações de Ianni (2004), supracitadas, revelando assim, a complexidade que envolve a questão racial e a desigualdade social dessa população perante o contexto histórico, político, econômico e cultural do Brasil.

Os equipamentos sociais a disposição da comunidade como: escolas, postos de saúde, segurança pública, áreas de lazer e oficinas profissionalizantes, os dados da pesquisa estão dispostos no Quadro 4.

\begin{tabular}{lllllc}
\hline Informações & Família A & Família B & Família C & Família D & Família E \\
\hline Centro de saúde & Sim & Sim & Sim & Sim & Sim \\
\hline $\begin{array}{l}\text { Presença da segurança } \\
\text { pública }\end{array}$ & Não & Não & Não & Não & Não \\
\hline $\begin{array}{l}\text { Locais para atividades } \\
\text { de lazer aos jovens }\end{array}$ & Não & Não & Não & Não & Não \\
\hline $\begin{array}{l}\text { Oficinas } \\
\text { profissionalizantes } \\
\text { para os jovens }\end{array}$ & Não & Não & Não & Não & Não \\
$\begin{array}{l}\text { Escola pública de } \\
\text { tempo integral }\end{array}$ & $\begin{array}{l}\text { Não. Uma de } \\
\text { tempo parcial. }\end{array}$ & Não & Não & Não & Não \\
\hline
\end{tabular}

Quadro 4. Disposição de equipamentos sociais no bairro Barroso. Fonte: Pesquisa direta, 2015.

A partir dos dados contidos no Quadro 4 percebe-se que, os equipamentos sociais, à disposição das famílias e dos jovens residentes na comunidade, não se fazem presentes, tampouco trabalhos sociais e/ou profissionalizantes. Destaca-se que, tal realidade é um problema social, inclusive objeto de ressalva pelo IPECE (2012, p. 86), uma vez que, segundo o organismo, evidencia-se que, nos bairros onde a prevalência são famílias de baixa renda, o Estado deve priorizar:

[...] às políticas públicas. A melhoria do bem-estar desta grande parcela da população [...] deve ser pautada pela eficiência e eficácia dos gastos municipais em forma de bens públicos e infraestrutura urbana de melhor qualidade. Por exemplo, obras de infraestrutura [...] como iluminação, pavimentação, saneamento, abastecimento de água, escolas, creches, postos de saúde [...] os bens públicos têm impacto positivo sobre a formação de capital humano das futuras gerações o que garantirá a saída dessas famílias da armadilha da pobreza, mitigando as tensões sociais causadas pela má distribuição da renda.

Além disso, a partir do Quadro 4, verifica-se que, as respostas da segurança pública, na comunidade são negativas, pois se apresentam de forma opressora, pois é realizado sob a perspectiva repressiva ao invés de ser preventivo. Na questão da educação, existem duas escolas de nível fundamental no bairro, ambas em tempo parcial. $\mathrm{O}$ atendimento à saúde, é comprometido pois, existe apenas um Centro de Saúde para atender uma população de aproximadamente 30 mil moradores, em dispor de atendimento pediátrico.

Portanto, conforme pode ser observado no Quadro 4, os equipamentos sociais, disponíveis para a população são limitados e precários e/ou inexistentes, revelando assim, um contexto social repleto de limitações.

No Quadro 5, buscou-se verificar a existência de uma relação entre a violência e a juventude na comunidade a partir de informações acerca dos motivos que levaram a violência entre os jovens assassinados nas famílias entrevistadas. 


\begin{tabular}{llllll}
\hline Informações & Família A & Família B & Família C & Família D & Família E \\
\hline $\begin{array}{l}\text { Motivos da violência } \\
\text { entre os jovens }\end{array}$ & $\begin{array}{l}\text { Falta de } \\
\text { oportunidade }\end{array}$ & As drogas & As drogas & As drogas & As drogas \\
\hline $\begin{array}{l}\text { Percepção das medidas } \\
\text { de combate à violência } \\
\text { entre os jovens }\end{array}$ & $\begin{array}{l}\text { Não existe, } \\
\text { só repressão } \\
\text { da polícia }\end{array}$ & Não existe & $\begin{array}{l}\text { Não existe, } \\
\text { só a polícia }\end{array}$ & Só a polícia & Não tem. \\
\hline
\end{tabular}

Quadro 5. Relação violência e juventude na comunidade. Fonte: Pesquisa direta, 2015.

Conforme pode ser observado no Quadro 5, a violência entre os jovens está intimamente ligada ao tráfico de drogas. Nas palavras da presidente da Associação Sol da Manhã, o motivo da:

[...] violência é a falta de emprego, é onde os jovens acabam se envolvendo com as drogas e no mundo da criminalidade, porque não têm oportunidade. No bairro, só existe um campinho de futebol para o lazer. A segurança pública é a grande dificuldade em falar sobre isso. Tenho até medo, porque existem policiais [...] corruptos, que chegam metendo a peia, mandando os jovens darem conta disso, darem conta daquilo, não querem nem saber qual o motivo que foi. [...] As crianças ainda crianças já são marginais, pois nunca tiveram nenhuma oportunidade. O caminho para a escola é perigoso [...] Outro problema sério que leva a violência é a droga. Os maiorzinhos quando os menores estão saindo do colégio eles já chamam convidando para vender droga, se sentindo os donos da situação, a polícia vem prende daqui alguns dias eles voltam e tão fazendo tudo de novo a mesma coisa (Entrevista realizada em 17/04/2015).

Portanto, a questão social que envolve a violência entre os jovens está intrinsicamente ligada ao tráfico de drogas, a falta de trabalho e lazer. Quanto ao trabalho da polícia, enfatizado pela entrevistada, percebe-se a inexistência de segurança pública. Ou melhor dizendo, essa medida trabalha sob o conceito de repressão ao invés da prevenção, desse modo, a polícia combate à violência com mais violência.

Acerca dessa dinâmica societal, nas comunidades carentes Iamamoto (2009, p.42), esclarece que: "[...] a imagem da pobreza é radicalizada: é o perigoso, o transgressor, o que rouba e não trabalha, sujeito à repressão e a extinção. São as "classes perigosas", e não mais laboriosas, destinatárias da repressão. Reforça-se assim a violência institucionalizada, colocando-se em risco o direito à própria vida".

Desse modo, a mesma autora deixa claro que as políticas sociais, devem ser planeadas e implementadas pelo Estado, sob a percepção da existência de inúmeras formas de expressão da questão social, no caso, materializadas na dinâmica social que estão inseridas essas famílias (esquecidas pelo Estado) que resultam no alto índice de violência entre os jovens da comunidade.

\subsection{Análise das falas dos sujeitos entrevistados}

Quanto as falas das famílias entrevistadas acerca da problemática tratada, as chefes das famílias que tiveram seus filhos assassinados relataram, respectivamente que:

O principal poblema é a segurança. Minha filha ainda menina, teve um relacionamento amoroso com um traficante, que pedia para os moradores emprestarem o apartamento pra 
ele, e, todo mundo emprestava porque o povo tem medo. Nessas idas aos apartamentos, em um dia pela manhã o traficante sai correndo atrás de um carro falando que ela tinha se atirado com a arma, mas a verdade é que ela ia me contar que tinha um caso com ele. Ai ele, pra ela não fazer isso atirou nela, depois o traficante pediu pra um vizinho levar ela pra um hospital e ele entrou em um carro e sumiu. Ela morreu a caminho do hospital, e, ele tá até hoje tá solto (Família A. Entrevista realizada em 17/04/2015).

Meu filho foi vítima de um assalto, ele reagiu, e aí mataram ele. Agora inventaram uma tal de Babilônia, entre o Barroso II e o Novo Barroso. Essa Babilônia realmente é uma "Babilônia". Ali sim é o verdadeiro inferno, eles matam de 3, 4 de uma vez, e, se a família não procura um jeito de busca os corpos eles enterram lá mesmo. Essa guerra é por causa de uns traficantes que tentam invadir a área dos outros. É horrível viver aqui. Pra você entra aqui só mandando avisar antes. Não existe nenhum tipo de trabalho social. Não vejo compromisso nenhum do Governo com a comunidade. Cada dia pior que o outro. As escolas [...] quando acontece deles tá em crise os estudante que moram no Barroso I não podem passa, porque tem que atravessar o bairro para poder ir. Segurança, o que a gente queria mesmo é que [...] formasse melhor os policiais porque quando eles batem, batem mesmo, até sangrar pela boca. Será que não tem outro meio para se resolver? Botá pra trabalhar pra vê se aprende alguma coisa, mas não fazem isso. Apenas batem, batem e batem pegam tudo o que eles tem, e se acabou. Aí eles falam "nóis perdemo aqui vamo ganha ali. [...] vamo faze outro assalto melhor pra pode recupera". Jovem a partir de 12 anos você já pode fica com medo, imagine o menino já com uma arma (Família B. Entrevista realizada em 17/04/2015).

Tenho 8 filhos, o mais jovem tinha de 16 anos. Mataram porque começou a se envolver com drogas [...] deixou de ir pra escola, dizia que ia, mas já não chegava mais no destino. Ficava na boca, vendendo droga, aparecia com uma michariazinha que eles dão pra agradar. Quando foi uma vez ele perdeu ou usou, o traficante foi lá e deu um tiro. Me contaram que ele ainda se levantou, ai o traficante falou: "ainda não morreu não", ai ele voltou e descarregou o revolver. Infelizmente, muitos jovens aqui pensam que ganham muito mais dinheiro vendendo droga do que estudando. (Família C. Entrevista realizada em 17/04/2015).

Tenho sete filhos. Mataram 3 de uma vez só (16, 26, 28 anos). O mais velho tinha emprego fixo. Parou um carro e deram 7 tiros. A até hoje não descobriram quem foi e nem o motivo, apenas comentário de que talvez tenha sido a polícia reservada, mas não acredito, pois eles não deviam nada pra polícia. Outros falam que foi uma discussão que aconteceu no campinho de futebol. A gente não pode querer saber muito qual foi o motivo que a gente tem até medo. Como eles mesmo diz você está sabendo demais, morre!!! (Família D. Entrevista realizada em 17/04/2015).

Tenho 3 filhos, o mais velho de 18 anos morreu. Os traficantes pegaram, prenderam a noite inteira deram peia à noite toda para ele dá conta de uma droga que tinha faltado. Quando soltaram ele saiu cambaleado chegou num canal aqui perto e morreu. Acho que ele se viciou também. (Família E. Entrevista realizada em 17/04/2015).

Considerando a entrevista e interconectando com nosso referencial teórico, encontramos evidências entre a vulnerabilidade social e a violência percebendo claramente que tais situações discorridas pelas entrevistadas fazem parte de seu cotidiano, que existe um conjunto de "circunstâncias", que remetem os jovens a viverem nesta dinâmica socioeconômica e cultural de violência. Pois, dado que esses sujeitos viviam sob condições de extrema pobreza, expostos a comportamentos de consumo e, sem condições econômicas de realizarem suas aspirações, acabam entrando para o tráfico de drogas e, por consequência, acabam fazendo parte dos números da violência, no caso, dos homicídios.

A afirmativa supracitada ancora-se nas histórias de vida dessas famílias, geralmente, numerosas, que vivem sem perspectiva de futuro levando os jovens a entrarem para o tráfico de drogas com a ilusão de mudarem essa realidade, ou simplesmente, para consumirem produtos que não estão ao seu alcance devido sua condição econômica. Por outro lado, também não existe 
qualquer tipo de projeto de inclusão social oferecido pelo Estado que possa instigar e propiciar a esses sujeitos uma mudança dessa realidade.

Acerca da realidade encontrada no estudo, Minayo (1991, p.57) recorda que:

[...] os que possuem uma limitada possibilidade de usufruir dos bens sociais, culturais e econômicos e que vivem na pele a face repressiva do Estado, desde seu nascimento, são [...] crianças, oriundas das famílias abandonadas, que lutam em meio à sociedade onde os direitos humanos e civis ainda são apenas um sonho, enquanto recebem propostas vantajosas, de lucro fácil, especialmente dos grupos do narcotráfico.

Bebendo da fonte de Marx (1987) a fim de desvelar as falas dos entrevistados compreendese que o contexto social que esses sujeitos estão inseridos só é passível de um entendimento considerando as relações contidas na estrutura de nossa sociedade capitalista, pois, ao mesmo tempo que fomenta o consumismo, instigando os indivíduos a saciar suas necessidades no âmbito do mercado, travestindo-os de consumidor, também os impelem. Dado que suas necessidades são socialmente determinadas por esta mesma estrutura através do processo de acumulação de capital que concentra as oportunidades e os meios de saciedade nas mãos de uma pequena parcela da população, negando à outra ainda maior, tais possibilidades.

Portanto, as relações entre vulnerabilidade, risco, exclusão e violência remetem a existência de um desequilíbrio entre a disponibilidade de recursos materiais e simbólicos e o acesso às oportunidades sociais, econômicas e culturais oferecidas pelo Estado, mercado privado e sociedade civil. Dessa forma, o estudo da precarização da sociabilidade e negação do status social evidencia não apenas contextos em que a violência emerge, mas complexifica critérios de entendimento e análise deste fenômeno social que perpassa a concepção do senso comum ancorado no não acesso à educação, pois o que existe nessa comunidade é uma sobreposição de carências materiais e simbólicas que fomentam a violência.

\section{CONCLUSÃO}

O artigo visou verificar se existe e como se dá a relação entre violência (homicídios) e a vulnerabilidade social, entre os jovens, das famílias associadas à Associação Sol da Manhã, acometidas pela violência no bairro Barroso, em Fortaleza - CE, entre os de 2012 e 2013. Perante a problemática, a questão da violência entre os jovens não é algo que possa ser explicado e muito menos resolvido por meio de respostas baseadas em medidas paliativas, como se faz presente no discurso político baseado no ideário neoliberal e incutido no imaginário popular pelo modelo societal dominante, a qual enfatiza que esse problema social pode ser resolvido a partir de uma melhor oferta, pelo Estado, na qualidade da educação, logo baixa renda, e da segurança pública.

Observamos que, tais variáveis contribuem para o agravamento do fenômeno violência. Todavia, fica evidente que existem outras medidas que necessitam serem enfrentadas e trabalhadas por atores públicos e privados afim de reverterem a perpetuação de sobreposição de carências que faz parte do cotidiano da vida dos sujeitos entrevistados.

Ressalta-se que, é inegável que em sociedades capitalistas, onde se fomenta o consumo, de forma exponencial, ao mesmo tempo em que se restringe o acesso aos bens de consumo por meio do dinheiro, a violência irá existir. No entanto, esse fenômeno tanto será mais exacerbado quanto maior for o abismo econômico entre a porção da população que possui maior renda e a que possui menor poder aquisitivo, o que nos parece uma realidade entre os jovens, na comunidade do Barroso. 
Portanto, o fator renda, se configura apenas como a porta de entrada para a condição de vulnerabilidade social desses jovens, caso contrário, recairíamos no reducionismo defendido pelo modelo neoliberal: baixa escolaridade, logo, sem qualificação profissional por consequência baixo nível de rendimentos, logo altos índices de violência.

Desse modo, o cerne da questão está na existência de sobreposição de carências ligadas às políticas públicas, como a não disponibilidade de equipamentos sociais (acesso à saúde, a educação, a segurança pública, ao lazer, etc), nas péssimas condições de habitação (elevado número de indivíduos por cômodo), no desemprego, nos estigmas presente nos olhares da população que carregam sentimentos de marginalização, deixados por terem sidos deixados à mercê da própria sorte. Ou seja, pela negligência do Estado e pela própria sociedade que culpabiliza esse contingente populacional por se encontrarem em situação de vulnerabilidade e/ou em risco social.

Assim, é possível afirmar que existe uma relação de inúmeros fatores, tais como: socioeconômicos, políticos, históricos e culturais, que condicionavam e ainda condicionam os jovens e suas famílias residentes na comunidade estudada, a situação de vulnerabilidade social por consequência na violência, ligada, principalmente ao tráfico de drogas, por se constituir numa economia paralela, fazendo com que esses jovens vivam sob uma perspectiva imediatista, pensando apenas no presente, justamente por não possuírem uma perspectiva de futuro

\section{REFERÊNCIAS}

ARENDT, Hannah. Sobre a Violência. Rio de Janeiro: Relume-Dumará, 1994.

BRASIL. Ministério do Desenvolvimento Social e Combate à Fome (MDS). Programa Bolsa Família: uma década de inclusão e cidadania. Brasília, 2014. Disponível em: http://www.mds.gov.br/webarquivos/publicacao/bolsa familia/Livros/Bolsa10anos_Sumex_Port.pdf. Acesso em: 10 mar. 2015.

CARDIA, Nancy; SCHIFFER, Sueli. Violência e desigualdade social. Cienc. Cult., São Paulo, v. 54, n. 1, p. 25-31, June 2002 . Disponível em: http://cienciaecultura.bvs.br/scielo.php?script=sci_artte xt\&pid=S0009-

67252002000100018\&lng=en\&nrm=iso. Acesso em: 03 Feb. 2021.

CARVALHO, Luiza. "Famílias chefiadas por mulheres: relevância para uma política social dirigida". In: Revista Serviço Social e Sociedade. N ${ }^{\circ}$ 57. Ano XIX. São Paulo: Cortez, 1998.

CASTEL, Robert. As metamorfoses da questão social. Petrópolis. Vozes 1998.

CFESS, Conselho Federal de Serviço Social. Código de Ética Profissional do Assistente Social. Brasília. 1993.

DEMO, Pedro. Pesquisa Social. Serviço Social \& Realidade. Franca, SP, v. 16, n.1, p.11-36, 2008.

DINIZ, Maria Helena. Curso de Direto Civil Brasileiro: direto de família. 17. ed. São Paulo: Saraiva, 2002. V. 5.
FURTADO, Celso. Formação econômica do Brasil. $15^{\mathrm{a}}$ ed. São Paulo: Nacional, 1977.

GIL. Antônio Carlos. Métodos e Técnicas de Pesquisa Social. 5. ed. São Paulo: Atlas, 1999.

IAMAMOTO. Marilda Villela. O Serviço Social no processo de reprodução das relações sociais. In: IAMAMOTO, Marilda Villela; CARVALHO, Raul de. Relações Sociais e Serviço Social no Brasil. São Paulo: Cortez; Lima/Peru: CELATS, 1982. p. 71-123.

Marilda Vilela e CARVALHO, Raul. Relações Sociais e Serviço Social no Brasil: Esboço de uma interpretação histórico-metodológica. 28 ed. Ed. Cortez. São Paulo: 2009.

Marilda Villela. Serviço Social em Tempo de Capital Fetiche. Capital Financeiro, Trabalho e Questão Social, 6 ${ }^{\mathbf{a}}$ edição. Editora Cortez, 2012.

IANNI, Octavio. Pensamento social no Brasil. Bauru: Edusc; Anpocs, 2004.

IPLANFOR. Revista Fortaleza 2040: iniciando o diálogo - por uma fortaleza de oportunidades, mais justa, bem cuidada e acolhedora. n. 2. Ano2. Fortaleza: Iplanfor, 2015.

INSTITUTO DE PESQUISA E ESTRATÉGIA ECONÔMICA DO CEARÁ. Informe no 43 Edição Especial - Perfil Municipal de Fortaleza. Tema VIII: O Mapa da Extrema Pobreza. Fortaleza: IPECE, 2012.

INSTITUTO DE PESQUISA E ESTRATÉGIA ECONÔMICA DO CEARÁ. Informe no 44 Edição 
Especial - Perfil Municipal de Fortaleza. Tema IX: As Condições Domiciliares dos Bairros. Fortaleza: IPECE, 2012.

INSTITUTO DE PESQUISA E ESTRATÉGIA ECONÔMICA DO CEARÁ. Informe $\mathbf{n}^{\mathbf{0}} \mathbf{6 6}$ Caracterização Espacial dos Homicídios Dolosos em Fortaleza. Domiciliares dos Bairros. Fortaleza: IPECE, 2013.

INSTITUTO DE PESQUISA E ESTRATÉGIA ECONÔMICA DO CEARÁ. Perfil Socioeconômico de Fortaleza. V.2 - IPECE, 2012 - Fortaleza - CE.

JANCZURA, Rosane. Textos \& Contextos (Porto Alegre), v. 11, n. 2, p. 301-308, ago./dez. 2012. Disponível em: https://revistaseletronicas.pucrs.br/ojs/index.php/fass/ar ticle/view/12173. Acesso em: 10 abr. 2015

MARX, Karl. O Capital. Vol. 1. Editora Diffel. São Paulo, 1987.

MINAYO. Maria Cecília de Souza. A Violência na Adolescência: Um Problema de Saúde Pública. In: Cadernos de Saúde Pública 6 (3). FIOCRUZ. Rio de Janeiro, 1991.

Maria Cecília de Souza. O Desafio do Conhecimento: pesquisa qualitativa em saúde. Hucitec, São Paulo, 2006.

RODRIGUES, Lea Carvalho. Propostas para uma avaliação em profundidade de políticas públicas sociais. AVAL Revista Avaliação de Políticas Públicas, ano I, vol. 1, n.1, jan-jun, 2008b.

SMITH, Adam. A riqueza das nações: investigação sobre sua natureza e suas causas. 2. ed. São Paulo: Abril Cultural, 1984, (Coleção “Os economistas”).

SOUZA, Celina. Políticas Públicas: uma revisão de literatura. Sociologias, v. 8, n. 16, jul./dez., 2006, p. 20-45.

WAISELFISZ, Júlio Jacob. Mapa da Violência 2013: Homicídios e Juventude Brasil. Rio de Janeiro: CEBELA, FLACSO; Brasília: SEPPIR/PR, 2012.

Júlio Jacob. Mapa da Violência II: Os Jovens do Brasil. Brasília: UNESCO, 2000.

WEBER, Max, 1864-1920. Economia e sociedade: fundamentos da sociologia compreensiva. Brasília, DF: Editora Universidade de Brasília (UnB): São Paulo, 1999. 586 p. 